\title{
INCREASING STUDENTS' LEARNING OUTCOMES THROUGH STUDENT TEAMS ACHIEVEMENT DIVISION (STAD) MODEL AT GRADE V SD
}

\author{
Desi Endang K. Sitepu ${ }^{1}$, Patri Janson Silaban ${ }^{2}$, Saut Mahulae $^{3}$ \\ 1,2,3 Universitas Katolik Santo Thomas, Medan, Indonesia \\ ${ }^{1}$ desi.endang@gmail.com, ${ }^{2}$ patri.jason.silaban@gmail.com, ${ }^{3}$ saut.mahulae@gmail.com
}

\begin{abstract}
This study aimed to improve students' learning outcomes through Student Teams Achievement Division (STAD) Model. This study was Classroom Action Research (CAR). The subjects of this study were 30 fifth grade students of SD Negeri 067246 Medan Tuntungan. The results in the pretest showed that 5 students reached the KKM, classically was $16.66 \%$ with an average score of 54.02 . In cycle I, 11 students reached the KKM, classically was $36.66 \%$ with an average of 68.72. In cycle II, 27 students reached the KKM, classically was $82.55 \%$ with an average of 82.55 . Learning through Student Teams Achievement Division (STAD) model was categorized as very good. This was seen from the results of observations of teacher activities in cycle I which was $72 \%$ and in cycle II it increased to $86 \%$. The implementation of learning was categorized as good. This was seen from the observation results of students' activities in cycle I which was $70 \%$ and in cycle II it increased to $82 \%$. Thus, implementing Student Teams Achievement Division (STAD) model improved students' learning outcomes on the ecosystem theme.
\end{abstract}

Keywords: learning outcomes, student teams achievement division model

\section{UPAYA MENINGKATKAN HASIL BELAJAR SISWA DENGAN MENGGUNAKAN MODEL PEMBELAJARAN STUDENT TEAMS ACHIEVEMENT DIVISION KELAS V SD}

\begin{abstract}
ABSTRAK
Penelitian ini bertujuan untuk meningkatkan hasil belajar siswa dengan menggunakan Model Student Teams Achievement Division dengan jenis Penelitian adalah Penelitian Tindakan Kelas (PTK). Subjek penelitian ini adalah 30 siswa kelas V SD Negeri 067246 Medan Tuntungan. Hasil penelitian menunjukkan persentase pada pretes siswa secara individual yaitu 5 siswa yang tuntas, secara klasikal yaitu 16.66\% dengan nilai rata-rata 54.02. Pada siklus I secara individual yaitu 11 siswa yang tutas, secara klasikal $36.66 \%$ yang tuntas dengan rata-rata 68,72. Pada siklus II secara individual yaitu 27 siswa yang tuntas, secara klasikal $82.55 \%$ dengan rata-rata 82.55. Pelaksanaan pembelajaran dengan Penerapan Model pembelajaran Student Teams Achievement Division (STAD) dikategorikan sangat baik. Hal ini dapat dilihat dari hasil observasi aktivitas guru pada siklus I sebesar $72 \%$ dan pada siklus II meningkat menjadi $86 \%$. Pelaksanaan pembelajaran dikategorikan sudah baik. Hal ini dapat dilihat dari hasil aktivitas observasi siswa pada siklus I sebesar 70\% dan pada siklus II meningkat menjadi 82\%. Maka dengan menerapkan Model pembelajaran Student Teams Achievement Division (STAD) pada tema ekosistem, dapat meningkatkan hasil belajar siswa.
\end{abstract}

Kata Kunci: hasil belajar, model student teams achievement division

\begin{tabular}{|c|c|c|}
\hline Submitted & Accepted & Published \\
\hline 23 Juni 2021 & 09 Agustus 2021 & 16 September 2021 \\
\hline
\end{tabular}

\begin{tabular}{|l|c|r|r|}
\hline Citation & $:$ & $\begin{array}{r}\text { K. Sitepu, D.E., Silaban, P.J., \& Mahulae, S. (2021). Increasing Students' Learning Outcomes through Student Teams } \\
\text { Achievement Division (STAD) Model at Grade V SD. Jurnal PAJAR (Pendidikan dan Pengajaran), 5(5), 1286- } \\
\text { 1295. DOI : http://dx.doi.org/10.33578/pjr.v5i5.8450. }\end{array}$ \\
\hline
\end{tabular}

\section{PENDAHULUAN}

Dalam perkembangan zaman yang terus berkembang dan teknologi yang sudah semakin canggih, maka kita sebagai warga negara juga harus bisa mengikuti perkembangan zaman tersebut, Dengan begitu kurikulum di sekolah juga diubah sehingga dapat bisa mengikuti perkembangan zaman, oleh karna itu maka kurikulum pendidikan yang berlaku sekarang di Indonesia adalah kurikulum 2013 yang menekankan pada kreativitas dan keaktifan peserta didik, yang di mana siswa dituntun lebih berperan aktif dalam proses pembelajaran dan di 
dalam kurikulum ini juga ditekankan agar lebih bisa menguasai teknologi. Proses belajar merupakan proses yang kompleks yang terjadi pada diri setiap orang sepanjang hidupnya, proses belajar itu terjadi karena adanya interaksi antara seseorang dengan lingkungannya (Silaban, \& Hasibuan, 2019). Model pembelajaran Student Teams Achievement Division (STAD) merupakan model yang sangat sederhana. Mengacu kepada berkelompok yang terdiri dari 4-6 orang. Dimana membentuk kelompok yang heterogen yaitu terdiri atas laki-laki, perempuan, berasal dari berbagai suku, memiliki kemampuan yang berbeda-beda. Model ini bertujuan untuk melatih siswa dalam bertukar pikiran antara satu dengan yang lain, menjalin interaksi, meningkatkan kepercayaan masing-masing peserta didik, dan memahami materi yang disampaikan sehingga terlaksana proses pembelajaran dengan tepat. (Jalaluddin 2020) Pendidikan merupakan proses tujuan-sadar. Tujuannya dapat diartikan untuk merumuskan hasil yang diharapkan siswa setelah mengalami pengalaman belajar. Salah satu tujuan pengajaran tercapai melalui hasil belajar siswa.

Berdasarkan data observasi dengan wali kelas V SD Negeri No. 067246 Medan Tuntungan, menunjukan bahwa masih banyak siswa yang masih memperoleh nilai yang kurang dari KKM yang telah ditentukan sekolah. Dengan demikian dapat dikatakan bahwa hasil belajar siswa masih domain rendah.

Tabel 1. Nilai Ulangan Harian Siswa

\begin{tabular}{cccccc}
\hline Mata Pelajaran & Nilai KKM & Jumlah Siswa & Presentase\% & Keterangan \\
\hline IPA & $70>$ & 10 & $33.33 \%$ & Tuntas \\
& & $70<$ & 20 & $66.67 \%$ & Tidak Tuntas \\
\multirow{3}{*}{ Bahasa Indonesia } & Jumlah & & 30 & $100 \%$ & Sangat Tuntas \\
& & $70>$ & 13 & $43.33 \%$ & Tuntas \\
& \multirow{2}{*}{ Jumlah } & $70<$ & 17 & $56.67 \%$ & Tidak Tuntas \\
& & 30 & $100 \%$ & Sangat Tuntas \\
\hline
\end{tabular}

Berdasarkan Tabel di atas dapat dilihat bahwa hasil belajar siswa pada semester genap tahun pembelajaran 2019/2020 dapat dilihat bahwa dari 30 siswa, pada mata pelajaran IPA yang tidak tuntas adalah 20 siswa atau $66.67 \%$ dan yang tuntas 10 siswa atau $33.33 \%$ yang mencapai KKM, Pada mata pelajaran Bahasa Indonesia yang tidak tuntas 17 siswa atau $56.67 \%$ dan yang tuntas 13 siswa atau $43.33 \%$ yang mencapai KKM.

Dengan melihat permasalahan yang terjadi di atas, maka peneliti melakukan perubahan perbaikan dalam proses pembelajaran. Salah satunya peneliti melakukan solusi dengan menerapkan model pembelajaran Student Team Achievement Division (STAD). Tujuan peneliti memberikan solusi dengan menerapkan model STAD ini untuk meningkatkan hasil belajar peserta didik didalam pembelajaran tematik. Dengan menerapkan model STAD ini peneliti berharap hasil belajar peserta didik meningkat, sehingga mencapai keberhasilan proses dan hasil belajar peserta didik.
Model pembelajaran Student Achievement Division Student (STAD) merupakan pembelajaran kooperatif yang didalamnya ada beberapa kelompok kecil peserta didik dengan level kemampuan akademik yang berbeda-beda saling bekerja sama untuk menyelesaikan tujuan pembelajaran.

Menurut Suherman, dkk. (2001) bahwa, "Kooperative Tipe Student Team Achievement Division (STAD) adalah guru menyampaikan suatu materi, kemudian siswa bergabung dalam kelompoknya yang terdiri dari empat atau lima orang untuk menyelesaikan soal-soal yang diberikan oleh pengajar".Setelah selesai mereka menyerahkan secara tunggal untuk setiap kelompok. Kemudian siswa diberikan kuis atau tes secara individu. Skor hasil kuis atau tes digunakan untuk menentukan skor individu dan untuk menentukan skor kelompoknya.

Menurut Dian (2011) bahwa, "Pembelajaran Kooperative Tipe Team Student Achievement Division (STAD) adalah salah satu 
model pembelajaran kooperatif dimana siswa belajar dengan bantuan lembaran kerja sebagai pedoman secara berkelompok, berdiskusi guna memahami konsep-konsep, menemukan hasil yang benar". Semua anggota diberi tanggungjawab, semua siswa secara individu diberi tes yang akan berpengaruh terhadap evaluasi seluruh kelompok, yaitu terdiri atas 4-5 orang. Setiap tim atau kelompok hendaknya memiliki 12 anggota yang heterogen baik jenis kelamin (laki-laki dan perempuan), ras, etnik, maupun berbagai kemampuan (tinggi, sedang, rendah) Tiap anggota tim menggunakan lembaran kerja akademik (lembar kerja siswa) dan kemudian saling membantu untuk menguasai bahan ajar melalui tanya jawab atau diskusi antar sesama anggota tim secara individu atau tim, tiap satu atau dua minggu diadakan evaluasi untuk mengetahui penguasaan mereka terhadap bahan akademik yang telah dipelajari.

\section{METODE PENELITIAN}

Dalam melakukan penelitian ini, jenis penelitian yang akan digunakan adalah penelitian tindakan kelas (PTK). Penelitian tindakan kelas adalah suatu pemecahan masalah yang memanfaatkan tindakan nyata berupa siklus dimana melalui proses kemampuan mendektekdi dan memecahkan masalah. Penelitian ini bertujuan untuk meningkatkan hasil belajar siswa pada tema ekosistem dengan menggunakan model pembelajaran Student Teams Achievement Division (STAD) di kelas V SD Negeri Negeri 067246 Kec. Medan Tuntungan. Pendekatan ini juga menggunakan dua jenis pendekatan yaitu pendekatan kualitatif dan pendekatan kuantitatif. Penelitian dilaksanakan SD Negeri 067246 Kec. Medan Tuntungan Tahun pembelajaran 2020/2021. Subjek penelitian adalah Siswa kelas V SD Negeri 067246 Medan Tahun Pembelajaran 2020/2021 dengan jumlah siswa 30 orang. Objek penelitian ini adalah dengan menggunakan model pembelajaran Student Teams Achievement Division dapat meningkatkan hasil belajar.

\section{Sumber Data}

Sumber data merupakan subjek dari mana asal data penelitian itu diperoleh. Sumber data ini adalah sumber data primer dan sekunder. Sekunder data primer yaitu data informasi yang dapat memberikan informasi tentang data penelitian. Data dalam penelitian ini siswa kelas V SD Negeri 067246 Medan Tuntungan tahun 2019/2020 terdiri dari 30 siswa. Hal ini menjadi pertimbangan untuk mengetahui sejauh mana keberhasilan siswa dalam pembelajaran yang telah diberikan tindakan dengan diterapkanya model pembelajaran Student Teams Student Achievement Division (STAD).

Sumber data Sekunder yaitu sumber yang tidak langsung memberikan data informasi penelitian kepada pengumpul data. Sumber data tersebut adalah hasil belajar yang dikumpulkan oleh guru wali kelas dan data pendukung dalam penelitian ini kepala sekolah SD Negeri 067246 Medan. Jenis data sekunder yang diganakan penelitian ini adalah aktivitas, tempat atau lokasi, dan dokumentasi.

\section{Alat Pengumpulan Data}

Alat yang digunakan untuk mengumpulkan data adalah observasi dan tes yang diuraikan sebagai berikut :

\section{Observasi}

Observasi atau pengamatan merupakan suatu teknik atau cara mengumpulkan data dengan mengadakan pengamatan terhada kegiatan yang sedang berlangsung. Observasi dilakukan dengan tujuan untuk mengamati proses pelaksanaan kegiatan pembelajaran yang sedang berlangsung, mengamati model yang digunakan guru ketika proses pembelajaran, mencari tau penyebab mengapa hasil belajar siswa kelas V di SD Negeri 067246 rendah tidak memenuhi KKM, sehingga peneliti melakukan observasi atau pengamatan dengan tujuan untuk meningkatkan hasil belajar siswa dengan baik.

\section{Lembar observasi guru}

Pada saat melakukan observasi, peneliti juga mengamati aktivitas guru dan siswa pada saat proses pembelajaran tematik pada tema ekosistem subtema komponen ekosistem pembelajaran 1 dan 2 berlangsung. 
Tes

Tes adalah salah satu instrumen pengumpulan data untuk mengukur kemampuan siswa/siswi dalam aspek kognitif atau tingkat penguasahan materi. Kriteria instrument tes hendaknya memiliki tingkat validitas (dapat mengukur apa yang hendak diukur) dan memiliki tingkat reabilitas (tes dapat memberikan informasi yang konsisten) (Darmadi, 2015). Tes yang diberikan dalam bentuk pilihan berganda dengan jumlah 60 soal sesuai dengan indikator yang hendak dicapai dan instrument dalam penelitian ini adalah evaluasi hasil belajar secara kognitif yaitu aspek pengetahuan $(\mathrm{C} 1)$, pemahaman $(\mathrm{C} 2)$, penerapan (C3).

\section{Uji coba Instrumen Tes \\ Validitas Tes}

Validitas berkenaan dengan ketepatan alat penilaian terhadap konsep yang dinilai sehingga betul-betul menilai apa yang seharusnya dinilai. Sebelum instrumen diuji coba, terlebih dahulu yang dilakukan peneliti adalah vadilitas terhadap tes tertulis.Instrument soal dikatakan valid jika $\mathrm{r}_{\mathrm{xy}}>\mathrm{r}_{\text {tabel. }}$

Menurut (Sugiyono, 2017:267) validitas merupakan derajad ketepatan antara data yang terjadi pada objek penelitian dengan daya yang dapat dilaporkan oleh peneliti.Dengan demikian data yang valid adalah data "yang tidak berbeda" antara data yang dilaporkan oleh peneliti dengan data yang sesungguhnya terjadi pada objek penelitian.

Untuk mengetahui validitas dari soal tersebut maka digunakan rumus sebagai berikut :

$$
\operatorname{Rxy}=\frac{N \Sigma x y-(\Sigma x)(\Sigma y)}{\sqrt{\left(N \Sigma X^{2}-\Sigma X\right)^{2}\left(N \Sigma Y^{2}-\Sigma Y\right)^{2}}}
$$

Jihad dan Haris, (2012: 180)

Keterangan:

$r_{x y}=$ Koefisien korelasi antara variabel

$\mathrm{X}$ dan variabel $\mathrm{Y}$

$\mathrm{N}$ = Banyaknya peserta tes

$\mathrm{X}=$ Nilai hasil uji coba

$\mathrm{Y}=$ Nilai rata-rata harian

Suatu instrumen dikatakan valid jika $r_{\text {hitung }}>r_{\text {tabel }}$, pada uji validitas ini harga $r_{\text {tabel }}$ sebesar 0,334 dengan teraf signifikan $5 \%$ dan jumlah siswa atau $\mathrm{N}$ sebanyak 30 siswa sedangkan suatu instrumen dikatan tidak valid jika $\mathrm{r}_{\text {hitung }}<\mathrm{r}_{\text {tabel }}$, pada uji validitas ini harga $r_{\text {tabel }}$ sebesar 0,309 dengan jumlah siswa 30 siswa.

\section{Uji Reliabilitas Instrumen}

Menurut Jihad, (2013 : 180), reabilitas soal merupakan ukuran yang menyatakan tingkat keajegan atau kekonsistenan suatu soal tes. Untuk mengukur tingkat kekonsistenan suatu soal tes. Rumus digunakan yang dinyatakan dengan

$r_{11}=\left[\frac{n}{n-1}\right]\left[\frac{s_{-\Sigma p q}^{2}}{s 2}\right]$

Arikunto,(2017: 115)

$r_{11}=$ Relibialitas tes secara keseluruhan

$\mathrm{N}=$ Banyaknya butir soal

Koefisien reliabilitas yang dihasilkan pada item soal intervensi item korelasi Jihad dan Haris (2013 : 180) seperti pada tabel dibawah ini :

Tabel 2. Intervensi terhadap Koefisien Korelasi

\begin{tabular}{cc}
\hline Koefisien Korelasi & Kriteria \\
\hline $0,90<r_{x y}<1,00$ & Sangat tinggi \\
$0,70<r_{x y}<0,90$ & Tinggi \\
$0,40<r_{x y}<0,70$ & Cukup \\
$0,20<r_{x y}<0,40$ & Rendah \\
$r_{x y}<0,20$ & Sangat rendah \\
\hline
\end{tabular}




\section{Hasil Pembelajaran Aktivitas Guru}

Untuk mengetahui pelaksanaan pembelajaran aktivitas guru dapat digunakan rumus :
Nilai $=\frac{\text { skor } \text { total }(\text { perolehan })}{\text { skor } \text { maksimal }} \times 100 \%$

Jihad dan Haris (2014: 130)

Tabel 3. Kriteria Penilaian dalam pembelajaran Siswa

\begin{tabular}{ccc}
\hline No & Rentang Nilai & Kriteria \\
\hline 1 & $81-100$ & Sangat Baik \\
2 & $70-70$ & Baik \\
3 & $60-69$ & Cukup \\
4 & $50-59$ & Kurang \\
5 & $0-49$ & Sangat Kurang \\
\hline
\end{tabular}

\section{Ketuntasan Hasil Belajar Siswa}

\section{Hasil Pelaksanaan Aktivitas Siswa}

Untuk mengetahui

pelaksanaan

pembelajaran aktivitas guru dapat digunakan rumus :
Nilai $=\frac{\text { skor total }(\text { perolehan })}{\text { skor } \text { maksimal }} \times 100 \%$

(Tampubolon,2014: 241)

Skala kriteria penilaian observasi oleh guru menurut Tampubolon (2014:35) adalah sebagai berikut :

Tabel 4. Kriteria Penilaian dalam pembelajaran Guru

\begin{tabular}{ccc}
\hline No & Rentang Nilai & Kriteria \\
\hline 1 & $81-100$ & Baik Sekali \\
2 & $61-80$ & Baik \\
3 & $41-60$ & Cukup \\
4 & $21-40$ & Kurang \\
5 & $0-20$ & Sangat Kurang \\
\hline
\end{tabular}

\section{Ketuntasan Belajar Siswa (Individual)}

Setiap siswa dikatakan tuntas belajarnya (ketuntasan individual) jika nilai yang diperoleh siswa telah mencapai nilai KKM 70, karena nilai KKM yang ditetapkan di sekolah yaitu 70 .

Rumus untuk menghitung ketuntasan individu adalah sebagai berikut :

$\mathrm{KB}=\frac{T}{T t} \times 100 \%$

(Trianto, $2010: 241$ )

Keterangan :

$\mathrm{KB}=$ Ketuntasan Belajar

$\mathrm{T}=$ Jumlah skor yang diperoleh siswa

$\mathrm{Tt}=$ Jumlah skor total

$\mathrm{KB}=\frac{T}{T t} \times 100 \%$
(Trianto, $2010: 241$ )

Keterangan :

$\mathrm{KB}=$ Ketuntasan Belajar

$\mathrm{T}=$ Jumlah skor yang diperoleh siswa

$\mathrm{Tt}=$ Jumlah skor total

\section{Ketuntasan Klasikal}

Satu kelas dikatakan tuntas belajarnya (ketuntasan secara klasikal) jika dalam kelas tersebut terdapat $>75 \%$ siswa yang telah tuntas belajarnya dari nilai KKM yang telah ditetapkan disekolah yaitu 70 . 


$$
\mathrm{P}=\frac{\sum \text { siswa yang tuntas belajar }}{\sum \text { siswa }} \times 100 \%
$$

Trianto, (2009:241)

\section{Rata-rata Hasil Belajar (Mean)}

Analisis data yang digunakan untuk mengetahui berhasilnya tindakan yang dilakukan dalam penelitian. Sesuai dengan $\tilde{x}=\frac{\sum x}{N}$

(Sudjana, 2016:109)

Keterangan : $\tilde{\mathrm{x}} \quad=$ Rata-rata

$\sum x=$ Jumlah seluruh skor

$\mathrm{N} \quad=$ Banyaknya Objek

tujuan penelitian, maka analisis data yang dilakukan adalah penilaian rata-rata.

Untuk mencari rumus rata-rata dalam kelas adalah sebagai berikut :

\section{Indikator Kinerja Penelitian}

Penelitian tindakan kelas diasumsikan bila hasil dilakukan tindakan perbaikan kualitas pembelajaran, maka akan berdampak terhadap perbaikan perilaku peserta didik dan hasil belajar (Tampubolon, 2013: 55).

Tabel 5. Interval Nilai

\begin{tabular}{ccc}
\hline Interval Nilai & Kategori & Makna \\
\hline $81-100$ & $\mathrm{~A}$ & Sangat Baik \\
$61-80$ & $\mathrm{~B}$ & Baik \\
$41-60$ & $\mathrm{C}$ & Cukup \\
$21-40$ & $\mathrm{D}$ & Kurang \\
$0-20$ & $\mathrm{E}$ & Sangat Kurang \\
\hline
\end{tabular}

\section{HASIL DAN PEMBAHASAN}

Proses belajar bertujuan untuk meningkatkan hasil belajar siswa. Faktor penting yang merupakan salah satu penentu keberhasilan siswa adalah model pembelajaran yang digunakan tidak monoton. Langkah pertama yang dilakukan peneliti adalah mengamati cara guru kelas $\mathrm{V}$ melangsungkan proses pembelajaran didalam kelas.. Kemudian setelah melakukan pengamatan pada guru, melakukan pretest kepada siswa untuk mengetahui pemahaman awal siswa mengenai tema 5 ekosistem dengan menggunakan model pembelajaran kooperative tipe Student Teams Achievement Division dan mengetahui kesulitan yang dialami oleh siswa dalam menjawab soal-soal mengenai tema 5 ekosistem. Pretest (Tes awal) diberikan kepada siswa yakni 14 .

\section{Ketuntasan Hasil Belajar Siswa Secara Individual Pada Pra Siklus}

Penelitian dimulai dengan memberikan tes kepada siswa dengan jumlah soal sebanyak 14 butir soal pilihan berganda dengan tujuan untuk mengetahui kemampuan awal siswa dan juga untuk mengetahui kesulitan-kesulitan yang dialami siswa dalam memahami materi pembelajaran yang hendak dijelaskan.

$$
\begin{gathered}
\mathrm{KB}=\frac{T}{T t} \times 100 \% \\
\text { Keterangan : } \\
\mathrm{KB}=\text { Ketuntasan Belajar } \\
\mathrm{T}=\text { Jumlah skor yang diperoleh siswa } \\
\mathrm{Tt}=\text { Jumlah skor total } \\
\mathrm{KB}=\frac{14}{28} \times 100 \%=50 \\
\text { soal pilihan berganda }
\end{gathered}
$$


Jurnal PAJAR (Pendidikan dan Pengajaran)

Volume 5 Nomor 5 September 2021 | ISSN Cetak : 2580 - 8435| ISSN Online : 2614 - 1337

DOI : http://dx.doi.org/10.33578/pjr.v5i5.8450

Tabel 6. Ketuntasan Hasil Belajar Siswa Secara Klasikal Pada PraSiklus

\begin{tabular}{ccc}
\hline Ketuntasan Belajar & \multicolumn{2}{c}{ Pra Siklus } \\
\cline { 2 - 3 } & Jumlah Siswa & Persentase \\
\hline Tuntas & 5 Siswa & $16.66 \%$ \\
Tidak Tuntas & 25 Siswa & $83.33 \%$ \\
Jumlah & 30 Siswa & $100 \%$ \\
\hline
\end{tabular}

Berdasarkan hasil belajar siswa pada pretest, diperoleh tingkt ketuntasan secara klasikal yaitu :

$\mathrm{P}=\frac{\sum \text { Siswa yang tuntas belajar }}{\text { Siswa seluruhnya }} \times 100 \%=16.6 \%$ yang tuntas belajar yaitu $: \frac{5}{30} \times 100 \%=16.66 \%$

yang tidak tuntas yaitu

$: \frac{25}{30} \times 100 \%=83.33 \%$

Untuk mengetahui persentase perubahan hasil belajar siswa secara klasikal pada pretes dapat dilihat pada gambar diagram dibawah ini :

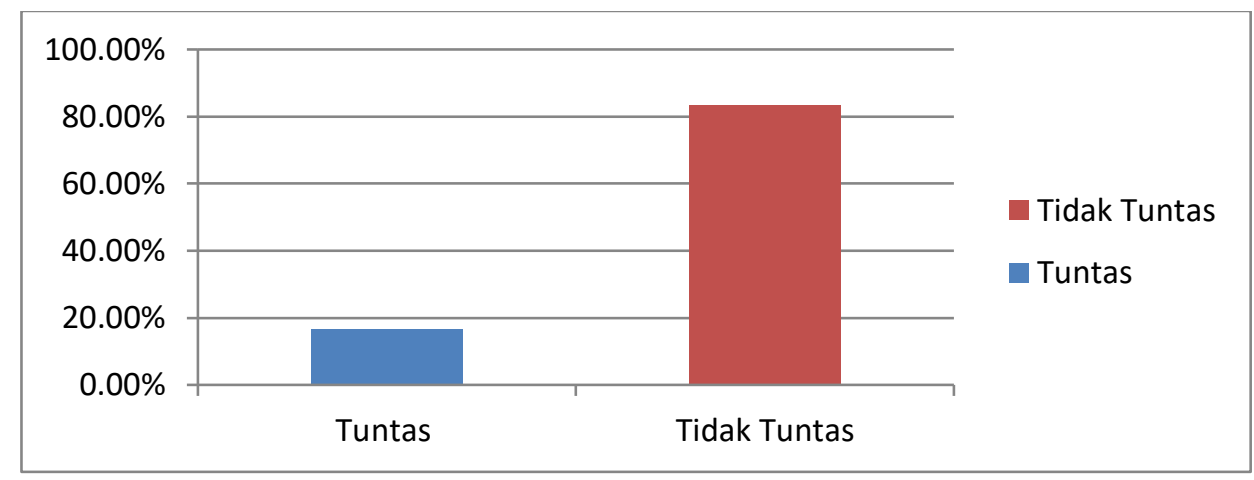

Gambar 1. Diagram Ketuntasan

\section{Ketuntasan Hasil Belajar Siswa Secara Klasikal Pada Siklus I}

Setelah diketahui hasil ketuntasan individu, selanjutnya ketuntasan hasil belajar secara klasikal yang dilihat dari hasil belajar siswa dalam satu kelas. Siswa yang dikatakan tuntas hasil belajarnya secara klasikal jika di dalam kelas tersebut terdapat $75 \%$ siswa yang mendapat nilai tuntas dan mencapai nilai dibawah Kriteria Ketuntasan Minimal (KKM) yang telah ditetapkan. Ketuntasan hasil belajar siswa secara klasikal dapat dilihat sebagai berikut :

Tabel 7. Ketuntasan Hasil Belajar Siswa Secara Klasikal Pada Postes Siklus I

\begin{tabular}{ccc}
\hline Keterangan & \multicolumn{2}{c}{ Siklus I } \\
\cline { 2 - 3 } & Jumlah Siswa & Persentase \\
\hline Jumlah siswa yang tuntas & 11 & $36.66 \%$ \\
Jumlah siswa yang tidak tuntas & 19 & $63.33 \%$ \\
Jumlah siswa & 30 & $100 \%$ \\
\hline
\end{tabular}

Untuk menghitung ketuntasan secara

$\Sigma$ siswa

klasikal dapat dihitung dengan rumus berikut

$\mathrm{P}=\boldsymbol{\Sigma}$ siswa yang tuntas belajar x $100 \%$ 
yang tuntas belajar yaitu: $\frac{11}{30} \times 100 \%=$ $36.66 \%$ yang tidak tuntas yaitu : $\frac{19}{30} \times 100 \%=$ $63.33 \%$

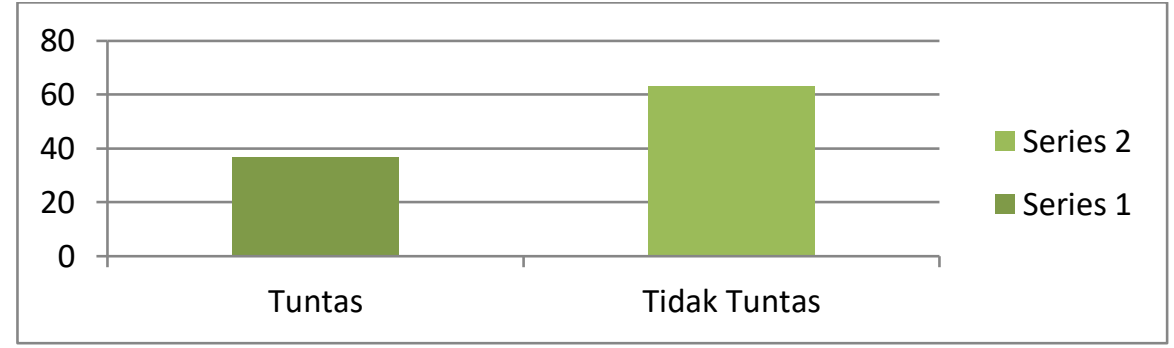

Gambar 2. Ketuntasan Hasil Belajar Siswa Secara Klasikal Pada Siklus I

\section{Rata-rata Hasil Belajar Siswa Pada Siklus I}

Dari hasil ketuntasan belajar individu dan klasikal maka dapat diperoleh nilai rata-rata belajar siswa yang dihitung dengan menggunakan rumus berikut:

$$
\begin{aligned}
& x=\frac{\sum x}{\sum N} \\
& x=\frac{2062}{30} \quad x=68.73 \text { (Baik) }
\end{aligned}
$$

Berdasarkan grafik di atas dapat dilihat bahwa kemampuan siswa dalam menguasai materi pembelajaran 1 dan 2 masih rendah, dikarenakan nilai rata-rata kelas mencapai $68.73 \%$.

Ketuntasan Hasil Belajar Siswa Secara Individu Siklus II
Pada akhir pembelajaran, setelah semua materi pembelajaran diajarkan guru kembali memberikan tes yang bertujuan untuk mengetahui tingkat keberhasilan atas tindakan yang diberikan. Dari hasil tes yang diperoleh peneliti pada penelitian tindakan kelas, diperoleh ketuntasan belajar siswa berikut: secara individual dengan rumus sebagai

$$
K B=\frac{T}{T t} \times 100
$$

Keterangan :

$\mathrm{KB}=$ Ketuntasan Belajar

$\mathrm{T}=$ Jumlah skor yang diperoleh siswa

$\mathrm{Tt}=$ Jumlah skor total

$\mathrm{KB}=\frac{27}{30} \times 100 \%=90$

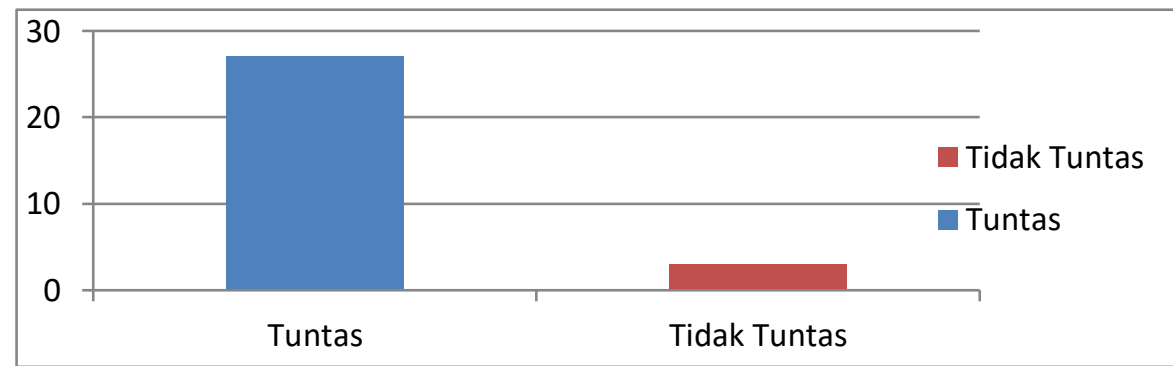

Gambar 3. Ketuntasan Hasil BelajaSiswa Secara Individual Pada Siklus II 
Berdasarkan diagram di atas dapat dilihat bahwa dari 30 siswa terdapat 27 siswa yang mendapat nilai tuntas dan mencapai KKM sedangkan 3 siswa mendapat nilai tidak tuntas dan tidak mencapai nilai KKM yang telah ditentukan yaitu 70. Ketuntasan secara individual dapat dilihat perbandingannya pada diagram berikut ini.

\section{Ketuntasan Hasil Belajar Siswa Secara Klasikal Pada Siklus II}

Berdasarkan hasil belajar yang diperoleh peneliti pada tindakan siklus II hasil belajar siswa secara klasikal mengalami peningkatan terhadap hasil belajar siswa secara klasikal yaitu $82 \%$.

Tabel 8. Ketuntasan Hasil Belajar Siswa Secara Klasikal Pada Postes Siklus II

\begin{tabular}{ccc}
\hline Keterangan & \multicolumn{2}{c}{ Siklus II } \\
\cline { 2 - 3 } & Jumlah Siswa & Persentase \\
\hline Jumlah siswa yang tuntas & 27 & $82.55 \%$ \\
Jumlah siswa yang tidak tuntas & 3 & $10 \%$ \\
Jumlah siswa & 30 & $100 \%$ \\
\hline
\end{tabular}

Untuk menghitung ketuntasan secara klasikal dapat dihitung dengan rumus berikut $\mathrm{P}=\boldsymbol{\Sigma}$ siswa yang tuntas belajar $\mathrm{x} 100 \%$

\section{$\Sigma$ siswa}

yang tuntas belajar yaitu
$: \frac{27}{30} \times 100 \%=82.55 \%$

yang tidak tuntas yaitu

$: \frac{3}{30} \times 100 \%=10 \%$

Ketuntasan hasil belajar secara klasikal dapat dilihat perbandingannya pada diagram berikut ini.

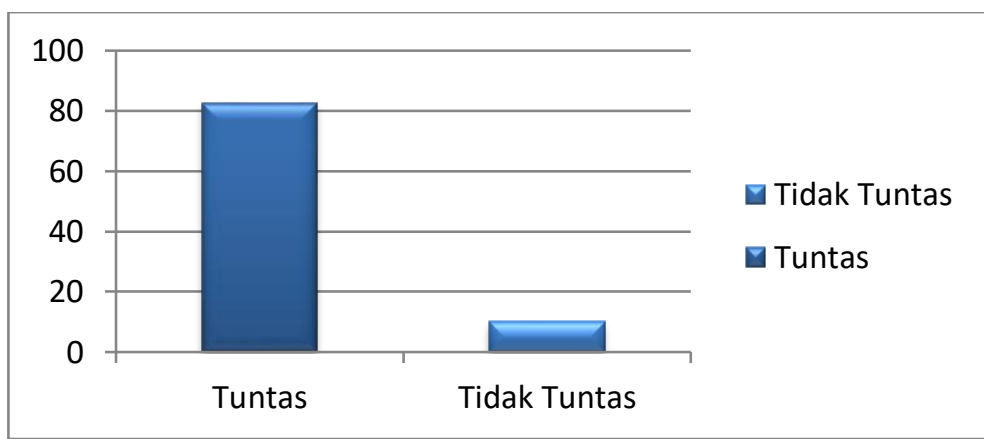

Gambar 4 Ketuntasan hasil belajar secara klasikal

\section{Rata-rata Hasil Belajar Siswa Pada Siklus II}

Dari hasil ketuntasan belajar individu dan klasikal maka dapat diperoleh nilai rata-rata belajar siswa yang dihitung dengan menggunakan rumus berikut:

$$
\begin{aligned}
& x=\frac{\sum x}{\sum N} \\
& x=\frac{24766}{30} \quad x=82.55
\end{aligned}
$$

\section{SIMPULAN DAN REKOMENDASI}

Berdasarkan hasil penelitian yan dilakukan oleh peneliti dengan Penerapan Model pembelajaran Student Teams Achievement Division (STAD) dapat meningkatkan hasil belajar siswa pada tema ekosistem kelas V SDN 067246 Medan Tahun pembelajaran 2020/2021, maka dapat disimpulkan sebagai berikut: Dengan menerapkan Model pembelajaran Student Teams Achievement Division (STAD) pada tema ekosistem, dapat meningkatkan hasil belajar siswa dan sudah memenuhi kriteria ketuntasan minimal (KKM) yang telah ditetapkan oleh sekolah yaitu 70. Hal ini dapat dilihat dari persentase ketuntasan 
belajar individu , klasikal, dan nilai rata-rata siswa yaitu ; pada pretes siswa secara individual yaitu 5 siswa yang tuntas, secara klasikal yaitu $16.66 \%$ dengan nilai rata-rata 54.02. Pada siklus I secara individual yaitu 11 siswa yang tutas, secara klasikal $36.66 \%$ yang tuntas dengan rata-rata 68.72. Pada siklus II secara individual yaitu 27 siswa yang tuntas, secara klasikal $82.55 \%$ dengan rata-rata 82.55. Pelaksanaan pembelajaran dengan Penerapan Model pembelajaran Student Teams Achievement Division (STAD) pada tema ekosistem di kelas V SD Negeri 067246 Medan Tuntungan Tahun Pembelajaran 2020/2021 dikategorikan sudah sangat baik. Hal ini dapat dilihat dari hasil observasi aktivitas guru pada siklus I sebesar $72 \%$ dan pada siklus II meningkat menjadi $86 \%$. Pelaksanaan pembelajaran dengan Menerapan Model pembelajaran Student Teams Achievement Division (STAD) di kelas V SDN 067246 Medan Tuntungan pada tema ekosistem dikategorikan sudah baik. Hal ini dapat dilihat dari hasil aktivitas observasi siswa pada siklus I sebesar $70 \%$ dan pada siklus II meningkat menjadi $82 \%$.

\section{DAFTAR PUSTAKA}

Silaban, P., dan Hasibuan. (2018). Meningkatkan Hasil Belajar Dengan Menggunakan Model Student Teams Achievement Division Tema Indahnya Kebersamaan Di Kelas IV. Jurnal Education FKIP UNMA, 6(2), 350-55.

Susanto, A. (2012). Teori Belajar \& Pembelajaran di Sekolah Dasar. Jakarta: Kencana.

Istirani dan Pulungan, I. (2019). Ensiklopedi Pendidikan. Medan: Media Persada.

Lestari, P., dan Hudaya, H. (2018). Penerapan Model Quantum Teaching Sebagai Upaya Meningkatkan Hasil Belajar Pada Mata Pelajaran IPS. Jurnal Of Education, $5(2), 45-60$.

Jalaluddin, M., Silaban, P. J., Sari, S. M. (2020). The effect of emotional intelligence on the results of learning mathematics in students elementary school. Advances in Mathematics: Scientific Journal, 9(12).
Setiawan, S. M. (2018). Telaah Teoritis. Jurnal Bimbingan Dan Konseling, 35(1), 31-46.

Rusman. (2014). Penerapan Model Pembelajaran Kooperative Tipe STAD Berbantuan Vidio Animasi Untuk Meningkatkan Hasil Belajar Komputer. Journal Pendidikan 6(3), 96-105. 